\title{
Poetry and Șūfism: Ibn al-Rūmī, from Asceticism to an Attempt to Transcend Language
}

\author{
Mahmuod Naamneh
}

Asceticism and mysticism (șūfism) were both topics which medieval Arabic poets addressed in their writings. An ascetic spirit dominated the conduct of life. This meant abstention from the material pleasures of this world and preparing oneself for the hereafter by means of modest living, prayer and abstinence. ${ }^{1}$ Șufism is perceived as a way to know and approach God, through thought, spiritual purity and other means, especially liberating oneself from earthly desires and material goods and devoting all of one's feelings and thoughts to God. ${ }^{2}$ Ibn al-Rūmī was influenced by the intellectual climate of the Abbasid period, especially by Suufĩ thought. From his poetic writings we may conclude that he attempted transcend his predecessors and to formulate new ideas, making creative use of language as well; for this reason I will call this experiment a "language explosion". ${ }^{3}$ By his groundbreaking use of language Ibn al-Rūmī was able to express the șüfi idea with precision; through poetry and through the șūfi experience he was able to create new meanings. ${ }^{4}$ This Abbasid poet, who was familiar with șüfi texts and șūfi thought, realized the potential of Șuffism for doing away with the obstacles posed by al'Ash'arī's writing, thought and theology, by going beyond intellectual knowledge and the traditional modes of religious worship and theological writing. This it did by adopting new forms of "exceeding the bounds" (al-tajāwuz), in the language of metaphors and incantations, excessive theurgy, ${ }^{5}$ ecstasy, dervish rituals and numerous unconventional theological ideas that stirred the Arab mind, ${ }^{6}$ such as "unification" (al-ittihāod), "incarnation" (al-hulūl), "illuminism" (al-ishrāq) and "revelation" (al-tajallī). ${ }^{7}$ Our Abbasid poet found this intellectual "explosion" useful for his poetry, which followed the rules of Arab prosody in its form, and in content dealt with the problems of his age. These șüfi ideas, the product of the Abbasid age as well, clearly influenced the thinking of Arab writers and intellectuals.

The evolution of șufi thought in the Abbasid period was driven by the social realities of the times, in particular by the emergence of a tendency towards asceticism, which paved the way towards mysticism. ${ }^{8}$ Asceticism gained ground in the Abbasid period, due to the nature of the contradictions that arose in the spirit of the age, as a necessary reaction to a tendency towards a life of opulence and pleasure-seeking. In the mosques penitents and admonitory preachers urged the people to adopt a life of asceticism and devotion to God and to abandon the pursuit

\footnotetext{
${ }^{1}$ See: Shalabī, 1980, 117.

${ }^{2}$ See: al-Hașrī, 2001, 870 .

${ }^{3}$ For a discussion of this term and its definition see 'Abd al-Raḥmān Badawī's study, in which he addresses the role played by the "language of excess" (lughat al-takhațtîn) in the al-Ḥusayn b. Manșūr al-Ḥallāj’s șūfì writings. See: Badawī, 1976, 26.

${ }^{4}$ On what poetry and Șūfism have in common see: al-Muqāliḥ, 1981, 10; Ḍāhir, 1997, 32; Bin 'amāra, 2000, 53-54.

${ }^{5}$ See, for example, al-Ḥusayn b. Manșūr al-Hallāj, al-Tawāsīn, 1997.

${ }^{6}$ Khansa, 1981, 29; Haddāra, 1981, 107; Snir, 1994-1995, 165-175.

${ }^{7}$ These terms are discussed in Su'ād al-Hakīm, al-Mu jam al-șūfì, 1981.

${ }^{8}$ See: Haddāra, $1988,84$.
} 
of earthly pleasure. ${ }^{9}$ Among the more prominent ascetics we may mention al-Fadīl b. 'Ayyāḍ and Hasan al-Bașrī in the mosque of Bașra, as well as 'Abd al-Wāhid b. Zayd, Ibrāhīm b. Adham, Wahīb b. al-Ward and Bishr al-Hafi. ${ }^{10}$ This trend, augmented by the spread of poverty among the working classes, gave rise to a class of mystics and a growing tendency towards mysticism. ${ }^{11}$ Ṣufism emerged from these circles of ascetics or, as Ibn al-Jawzī noted in his Talbīs Iblīs, "Șūfism [arose] from among the ascetics". ${ }^{12}$

The cynicism of the age was apparently itself a motive for adopting a life of asceticism and mysticism, as happened with Ibn al-Rūmī, whom a life of excess led to asceticism. This is a phenomenon already noted by 'Alī Ibrāhīm in his study Zuhd al-mujjān. ${ }^{13}$

In addition to the above-mentioned causes for the emergence of a mystical tendency in the Abbasid period, there were also religious and psychological motives, aroused by personal experiences such as estrangement and deprivation, that made people like Ibn al-Rūmī adopt Sūfism as a way towards personal salvation. ${ }^{14}$ As Abū Zayd explains, ${ }^{15}$

Asceticism or mysticism at some levels may be traced back to a spirit of despair that took hold of some individuals, despair of righteousness and of change for the better, fear of having one's shameful sins exposed, a sense of wrongdoing, of shaken values and a disturbed equilibrium in life. As a result, those who were powerless retreated into asceticism and distanced themselves from life's temptations.

Șüfism became widespread and developed numerous creeds and sects. The best-known dispute among them was that between the supporters of 'Ali and the Abbasid caliphs. The latter felt close to the Prophet and to 'Alī b. Abì Țâlib, argued that he should have been appointed caliph after the Prophet's death, praised his qualities as scholar and claimed that he was superior in standing, knowledge, letters and faith to the caliphs. ${ }^{16} \mathrm{Ibn}$ al-Rümì belonged to the 'Alawi school and was clearly influenced by its arguments, although he also close to some Abbasid caliphs and governors.

Ibn al-Rūmìs initial theological forays (he experimented with mysticism, materialism and speculative dogmatism [i'tizāl], but not all these came to fruition) seems to have been into $i^{\prime} t i z a \bar{l}$. He attempted to approach the thinking of the Mu'tazilites through the school of free will (al-qadariyya), as can be seen in some of his poems, for example: ${ }^{17}$

The creed of justice and monotheism unites us

Not the similar ones who dissuade and disavow

This declaration is evidence for Ibn al-Rūmīs Mu'tazilite inclinations. ${ }^{18}$ Justice and monotheism, the creed that unites them according to the poem, are two basic principles of the

\footnotetext{
${ }^{9}$ See: Abū Zayd, 1994, 27.

${ }^{10}$ See: al-Aṣbahān̄̄, 1997, 84.

${ }^{11}$ See: Amīn, 1969, 121.

12 See: Ibn al-Jawzī, 1997, 17.

${ }^{13}$ See: Abū Zayd, 1994.

${ }^{14}$ Ibid., 30.

15 Ibid.

${ }^{16}$ Ibid., 59.

${ }^{17}$ See the commentary and the poem in: al-Amīn, 1986, 153.

${ }^{18}$ The Mu tazila is a theological-philosophical school derived from Abbasid thought, which in turn was influenced greatly by ancient Greek philosophy. The school was founded in al-Bașra at the beginning of the second century AH by
} 
Mu'tazila, which believed that man must strive towards attaining the ranks of the just and perform every action in a just and measured manner, in line with the Qur'annic statement: "We have created all things in due measure". ${ }^{19}$ The Mu'tazila's position on God's attributes was derived from its belief in tawhìd, God's oneness. It therefore maintained that God's attributes as expressed in the Qur'ān must not be understood in their literal meaning. The conclusion of the Mu'tazila from this line of argument was that the Qur'ān was not to be considered God's word, but rather an act of God. ${ }^{20}$ However, this conclusion cannot be applied to Ibn al-Rūmī, whose uncertainty and dissimulation can be seen in his texts.

Ibn al-Rūmī's path towards asceticism may seem rather unconventional, but was perhaps not so in the Abbasid period, as we noted above, a period in which an "asceticism of the wanton" was common. Through his shameless behavior Ibn al-Rūmī tried to console his grief- and painstricken soul, as he writes in the following lines: ${ }^{21}$

My old age loomed, in which I exulted

Like the edge of an adorned first beard

Youth took possession and ran ever more

In the fields of my futility

Whoever has been wronged by time

Deserves to amuse himself more than any man.

In these verses Ibn al-Rūmī presents his philosophy concerning life's afflictions. He says that time has brought him old age and worries, which he warded off by rejoicing like a young man. The more he was beset by old age and futility, the more he escaped into pleasures. Ibn al-Rūmī declares that a person afflicted by evil has the right to refresh himself with amusements. ${ }^{22}$ Ibn al-Rūmì was driven to asceticism by the general tragic situation in Abbasid society, its deviations and the social evils that beset it, such as avarice, spite, miserliness and deception, and the duplicity and hypocrisy of the rulers. ${ }^{23}$ In the following line he criticizes the hypocrisy in society in the manner of the ascetics: ${ }^{24}$

Hypocrisy took possession of his nature, like a fox

Its wickedness in its frenzy rejected kindness.

The evil of hypocrisy dominates men and, in the simile used by Ibn al-Rūmī, gives them the attributes of a fox in its frenzy. He constantly discusses mankind's quarrel with time, ${ }^{25}$ as if he were a believer in the unavoidability of fate. Here is his depiction of someone who tries to escape his fate, with destiny the only victor: ${ }^{26}$

0 you who flees from his fate

Fate has reached you on its horse

Driving ?????

Wāṣil b. 'Ațầ' al-Bașrī. Its theology preferred the use of logic over textual stipulations. It debated such complex theological topics as the denial of God's attributes ( $t a$ ' $t \bar{l} l$ ), extraction of human actions from God's will, the status of the perpetrators of great sins, God's promises and threats towards His servants on earth, and promotion of good and forbidding of evil. See: al-Shahrastānī, 2000, 39-40; al-Baghdādī, 1995, 112-115.

${ }^{19}$ Q 54:49.

${ }^{20}$ See: al-Shahrastān̄̄, 2000, 40.

${ }^{21}$ See the verses in: Ibn al-Rūmī, 1974, 83.

${ }^{22}$ See the commentary on these verses: Abū Zayd, 1994, 101.

${ }^{23}$ See: Nāfi', 2008, 126.

${ }^{24}$ See: Ibn al-Rūmī, 1974, 212.

${ }^{25}$ See: Nāfi', 2008, 131.

${ }^{26}$ See the verses in: Ibn al-Rūmī, 1974, 215. 
To a distance that cannot be reached

Its face following its head

Like the summer day follows the night.

In this metaphorical image fate appears as frightening roaming horseman who pursues a man who is terrified of death and constantly flees from it. ${ }^{27}$

As noted above, Ibn al-Rūmī's poems reflect șüfi thought. They urge one to adopt an ascetic way of life and spiritual modesty. The poems are replete with easily identifiable șüfi terms and ideas typical of the Gnostic transcendentalism and illuminism adopted by mystics of the Middle Ages. ${ }^{28} \mathrm{Ibn}$ al-Rūmī's frequent use of these ideas in his poetry can be seen in the following examples. In a poem calling for asceticism he says: ${ }^{29}$

One continuously invokes the Eternal One

Alone in the darkness of the night

In his bowels his fears cause

Flames to sting his liver

Whenever he underwent (God's ) admonishments

Tears flowed continuously from his ey $\mathrm{e}^{30}$

Saying: 0 my utmost hope

??? from whom I fear tomorrow

Woe unto my eyes which have seen evil

Woe unto my heart that has thought evil.

In these verses Ibn al-Rūmī describes a man's private conversation with his Creator. The conversation takes place at night, a time when a man can be alone with God. The man's soul is aflame in fear of God's wrath (perhaps because Ibn al-Rūmī recognizes the sins of excess he had committed in the days before he became an ascetic). When he mentions God's promises and admonishments for His servants his tears flow in fear. In his conversation with God he describes Him as his "utmost hope" in this plague-stricken and sorrowful world. He beseeches Him and blames himself for the sins of the past.

The poet's pain and tears, his burning heart and the sense of sin expressed in this poem, all testify to its șüfí nature. To become a Șūfĩ one must first be a murīd ("novice"), a stage during which one is expected to repent with honest tears before God, when alone in His presence at a süfi hadra ("gathering") at night. ${ }^{31}$ In this poem Ibn al-Rūmī eventually reaches God, his "utmost hope", the same extremity reached by the mystics following their sufferings in this world.

In the course of reading Ibn al-Rūmī's poetic oeuvre I encountered numerous șüfí ideas which superficially, when given their ordinary meanings, appear as traditional ideas used by poets, but which in their allegorical-transcendental interpretations can all be given purely șüfi meanings which can be encountered among the mystical poets of the Middle Ages, who wrote about wine, drunkenness, love, passion and carousing, all of which were in fact used

\footnotetext{
${ }^{27}$ See: Nāfi', 2008, 131.

${ }^{28}$ For more on these ideas see: Pellat, 1971, 707-708, 217-231.

${ }^{29}$ See the verses in: Dayf, 1975, 475.

${ }^{30}$ The eye is frequently used by Șūfīs to indicate the means for attaining the "great truth" (God). It is the instrument whereby the mystics express God's beauty and the beauty of His names and attributes. On the meaning of the eye in $s \bar{u} f i$ writings see: Hakki, 1980, 93. In the poem under discussion here Ibn al-Rūmī seems to use the word "eye" in a sense similar to the one used by the mystics.

${ }^{31}$ See: Al-Allaq, 1983, 43.
} 
allegorically in reference to God. Thus the love they wrote about was love of the divine, and the same is true of the others. ${ }^{32}$ This can be seen in the writings of Ibn al-Fāriḍ and Muhyī al-Dīn b. al-'Arabī in his famous Turjumān al-ashwāq, ${ }^{33}$ Jalāl al-Dīn al-Rūmī in his al-Mathnawi, ${ }^{34}$ alHallāj, Rābi'a al-'Adwiyya, 'Umar al-Khayyām and al-Suhrawardī ("the Murdered Master") in his Hayākil al-nūr. ${ }^{35}$

Many of Ibn al-Rūmī's poems about wine and love appear licentious at first glance. However, I believe that they express șüfi ideas. This claim is supported first of all by the previously noted pseudo-contradiction inherent what we called above "asceticism of the wanton", and also by the fact, also discussed above, that Ibn al-Rūmì sought to extend language and create a kind of poetic "modernism", especially with respect to his masochistic desire to express his pain and grief, and the blows that he suffered from fate. Here are a number of examples. In one poem he says: ${ }^{36}$

Al-'Irāqī made wine (al-nabìdh) and the imbibing thereof licit

And said: The two forbidden things are drinking bouts and drunkenness

Al-Hijāzī said: The two (water and wine) are one

And although they are different, wine (al-khamr) is permitted.

I shall take from both their respective views

And drink both, without differentiating between the carrier and the load.

In these verses Ibn al-Rūmī expresses his views on a disputed issue in Islam, namely whether or not wine is forbidden. One scholar (al-'Irāqī) maintains that drinking al-nabīdh is permitted, but drinking bouts and drunkenness are forbidden, while another scholar is of the opinion that al-khamr is like water, and therefore may be drunk without restriction. Ibn al-Rūmī summarizes the dispute and says "I will drink al-khamr and adopt both opinions". The question we must ask here is if by al-khamr he means the usual kind of wine, with alcohol. The answer can hardly be in the affirmative, since no know school of Islamic jurisprudence permits drinking wine; in fact, both of the views mentioned in the poem do not correspond to Islamic law. We may therefore hypothesize that here he speaks about the șüfi concept of "divine wine". This would make the debate in the poem comprehensible: Does Islamic law permit drinking "divine wine", or even to become inebriated with it? Or perhaps what is meant by "bouts and drunkenness" is the șüfi gathering (haḍra) at which the novice converses with God. During the period in question the status of Șufism, whether it was to be accepted or rejected, was in dispute. The poet's statement that he would adopt both views and drink wine perhaps implies that following the misfortunes that he had suffered he repented and that now that he was living an ascetic pious life he addresses the deity using the terms "wine" and "drunkenness" in their șūfì sense. ${ }^{37}$

Elsewhere Ibn al-Rūmī again speaks about this wine and states that whoever refrains from drinking it misses out on the enjoyment of life:

The world is hearing

Cupbearers and drinking companions

\footnotetext{
32 See: Scheindlin, 1991.

${ }^{33}$ See: Ibn al- 'Arabī, 1966.

${ }^{34}$ See: al-Rūmī, 1995.

${ }^{35}$ See: al-Suhrawardī, 1957.

${ }^{36}$ See the verses in: Ibn al-Rūmī, 1974, 984.

${ }^{37} \mathrm{Cf}$. the interpretation of these verses in al-Tațāwī, 1999, 130.
} 


\section{If you miss out on this}

There goes the world ${ }^{38}$

Our approach is supported by what we know in fact about Ibn al-Rūmī. After all, it is hardly likely that this man, who wallowed in grief and pain after he had lost everything that connected him to life on earth, would promote earthly pleasure. The only possible answer is that we must pursue an allegorical mystical interpretation, according to which Ibn al-Rūmī here calls on his readers to draw near to God and to join him on his șüfi path.

\section{CONCLUSION}

Ibn al-Rūmī was a talented and experienced poet who composed pioneering and path-breaking verses. He tried to innovate in the construction of his poems while still remaining within the bounds of accepted poetic standards. His attempts at transcending bounds led him to mystical ideas, based on his conviction that șüfi poetry and the șüfi experience would help him create new meanings. He used a number of șüfì ideas which were consistent with the ascetic and mystical way of life that he adopted towards the end of his life, after all doors were closed to him and he renounced the temporal world. He was also linguistically innovative, using Qur'ānic terms in their contextual Qur'ānic meanings in order to express his own private poetic meanings.

\section{References}

Abū Zayd, 'Alī. Al-Ru’ya al-fikriyya wal-tashkīl al-jamālī fī shi'r Sayyid al-Ḥamrī. Cairo: Dār al-ma'ārif, 1984. Abū Zayd, 'Alī Ibrāhīm. Zuhd al-mujjān fī al-‘aṣr al-`abbāsī. Cairo: Dār al-ma‘ārif, 1994.

Abū Zayd, Sāmī \& Zahdī 'Abd al-Rahīm. “Qaḍayā mu'jamiyya fī shi'r Ibn al-Rūmī”. Majallat majma' al-lugha al'arabiyya al-urdunnī 84 (2004), 139-194.

Al-Allaq, Ali Gafar. The Artist Proplem in Abdal Wahhāb Al- Bayātīs' Poetry. Exeter: Exeter University press, 1983.

Al-Amīn, Aḥmad. Zuhr al-islām. Beirut: Dār al-kitāb al-`arabī, 1969.

Al-Amīn, Muḥsin. A`yān al-shī‘a, edited by Ḥasan al-Amīn. Beirut: Dār al-ma‘̄ārif, 1986.

Al-Așbahānī, Abū Na'īm. Ḥilyat al-awliyā’, vol. viii, edited by Mușțafā 'Abd al-Qādir 'Ațā. Beirut: Dār al-kutub al'ilmiyya, 1997.

Badawī, 'Abd al-Raḥmān. Shațahāt al-șūfiyya. Kuwait: Wikālat al-maṭū̄āat, 1976.

Al-Baghdādī, Ibn Ṭāhir. Al-Farq bayna al-firaq, edited and with a commentary by Ibrāhīm Ramaḍān. Beirut: Dār alma'rifa, 1995.

Bin`amāra, Muhammad. Al-Ṣūfiyya fĩ al-shi`r al-maghribī al-mu’āṣir, al-mafāhīm wal-tajalliyāt. Casablanca: alMadāris, 2000.

Ḍahir, 'Ādil. “al-Tashakhṣun wal-takhaț̣ī fī aghānī Mihyār al-Dimashqī”, Fuṣūl 16 (1997), 199-217.

Ḍayf, Shawqī. Al-`Așr al-‘abbāsī al-thānī. Cairo: Dār al-ma‘ārif, 1975.

Haddāra, Muḥammad Muṣțafā. “al-Naz'a al-ṣūfiyya fī al-shi'r al-‘arabī al-ḥadīth”, Fuṣūl 1 (1981), 107-120.

Haddāra, Muḥammad Mușțafā. Ittijāhāt al-shi'r al-‘arabī fī al-qarn al-thānī al-hijrī. Beirut: Dār al-`ulūm al'arabiyya, 1988.

Al-Ḥakīm, Su`ād. Al-Mu jam al-ṣūfì. Beirut: al-Mu’assasa al-jāmi'iyya lil-dirāsāt wal-nashr, 1081.

Hakki, Ismail. Translation and Commentary of Fusus Al-Hikam. London: Oxford University, 1980.

Al-Ḥallāj, al-Ḥusayn b. Manșūr. Al-Dīwān yalīhi kitāb al-Ṭawāsīn, edited by Abū Ṭarīf al-Shībī. Cologne: Dār aljamal, 1997.

\footnotetext{
${ }^{38}$ See the verses in: Ibn al-Rūmī, 1974, 1563.
} 
Ibn al-`Arabī, Muhyī al-Dīn. Turjumān al-ashwāq. Beirut: Dār Ṣādir, 1966.

Ibn al-Jawzī, 'Abd al-Raḥmān. Talbīs Iblīs. Beirut: Maktabat al-kutub al-thaqāfiyya, 1997.

Ibn al-Rūmī. Dīwān Ibn al-Rūmī, edited by Ḥusāyn Nașṣār. Cairo: Maktabat dār al-kutub, 1974.

Khansa, Wafĩq. Dirāsāt fī al-shi'r al-sūrī al-ḥadīth. Algiers: Dār al-ḥaqā’iq, 1996.

Al-Muqāliḥ, 'Abd al-`Azīz. Al-Shi'r bayna al-ru’yā wal-tashkīl. Beirut: Dār al-‘awda, 1981.

Nāfic, 'Abd al-Fattāḥ Ṣāliḥ. Al-Shi'r al-‘abbāsī qaḍāyā wa-ẓawāhir. Amman: Dār Jarīr, 2008.

Pellat, Charles. “Ibn Al-Aarabī”, The Encyclopaedia of Islam, New Edition, Volume 3 (1971), 707- 708.

Al-Rūmī, Jalāl al-Dīn. Al-Mathnawī, translated into Arabic by Muḥammad Jamāl al-Hāshimī. Beirut: Dār al-ḥaqq, 1995.

Scheindlin, R, P. The Gazelle- Medieval Hebrew Poems on God, Philadelphia, 1991.

Al-Shahrastānī, Muḥammad b. 'Abd al-Karīm. Al-Milal wal-niḥal, edited by Muhammad 'Abd al-Qādir al-Fāḍilī. Beirut: al-Maktaba al-'așriyya, 2000.

Snir,Reuven. "Mysticism and Poetry in Arabic Literature”, Orientala Suecana (1994- 1995), 164-175.

Al-Suhrawardī, Yahyyā b. Habash al-Maqtūl. Hayākil al-nūr, edited and with an introduction and commentary by Muhammad Abū Rayyān. Cairo: al-Maktaba al-tijāriyya al-kubrā, 1957.

Al-Tațāwī, ‘Abdullāh. Al-Naẓariyya wal-tajriba 'inda a'lām al-shi'r al-`abbāsī. Cairo: Dār ghurayyib, 1999. 